\title{
Was the SAFTA (Phase II) Revision Successful? A Case Study of Bangladesh's RMG Exports to India
}

\section{Namra Awais*}

\begin{abstract}
Bangladesh has experienced phenomenal growth in its readymade garments (RMG) sector and become the world's second-largest RMG exporter after China. Given the country's robust position in this context, many observers expected that the SAFTA revisions under Phase II - which allowed Bangladesh's apparel products duty-free and quota-free access to the Indian market - would lead to a surge in Indian imports of apparel and RMGs. However, this did not materialize. This study analyzes Indo-Bangladesh trade in RMGs in order to determine the underlying reasons for this anomaly. Using Balassa's concept of revealed comparative advantage, the study establishes the strong comparative advantage enjoyed by Bangladesh though the results also show a lack of effective trade complementarity between the two countries. Overall, the findings suggest that India enjoys economies of scale in RMG production - as Bangladesh's competitor, India has artificially maintained a secure regime through a combination of domestic export incentives and nontariff measures to restrain imports.
\end{abstract}

Keywords: Bangladesh, India, comparative advantage, liberalization, RMGs, SAFTA.

JEL classification: F13, F14, F15.

\section{Introduction}

As low-technology manufactures, textiles and garments (T\&G) occupy a pivotal place in the export portfolio of the larger economies within the South Asian Association for Regional Cooperation (SAARC), including Bangladesh, India, Pakistan and Sri Lanka (Table 1). Of these, Bangladesh has experienced phenomenal export growth in the readymade garments (RMG) sector, becoming the world's second-largest exporter of clothing after China. This particular segment has become the backbone of the economy, with the clothing sector accounting for 78 percent of total exports in 2014

\footnotetext{
* Teaching and Research Fellow, Graduate Institute of Development Studies, Lahore School of Economics.
} 
compared to a negligible 0.001 percent in 1976. Today, despite the fact that Bangladesh is categorized as a least developed country (LDC), its RMG sector is seen as a promising success story. The sector employs approximately 4 million people, of which 85 percent are women.

\section{Table 1: Clothing and textiles as a percentage of total merchandise exports}

\begin{tabular}{ccccccccc}
\hline & \multicolumn{2}{c}{ Bangladesh } & \multicolumn{2}{c}{ India } & \multicolumn{2}{c}{ Pakistan } & \multicolumn{2}{c}{ Sri Lanka } \\
\cline { 2 - 9 } Year & Clothing & Textiles & Clothing & Textiles & Clothing & Textiles & Clothing & Textiles \\
\hline 2009 & 78.84 & 5.87 & 7.28 & 5.52 & 19.16 & 37.15 & 44.45 & 1.89 \\
2010 & 77.39 & 6.58 & 4.96 & 5.67 & 18.36 & 36.66 & 40.58 & 2.00 \\
2011 & 78.62 & 7.77 & 4.84 & 5.06 & 17.93 & 35.78 & 41.14 & 1.93 \\
2012 & 78.75 & 6.50 & 4.66 & 5.15 & 17.15 & 35.43 & 42.70 & 2.41 \\
2013 & 80.72 & 6.50 & 5.38 & 6.04 & 18.11 & 37.18 & 44.19 & 2.31 \\
\hline
\end{tabular}

Source: Author's calculations based on data from the WTO Statistics Database.

Bangladesh was not traditionally an exporter of textiles and garments (T\&G): till the 1970s, its exports were dominated by jute and jute products. However, it was a beneficiary of the Multi-Fiber Agreement, which controlled clothing quotas and supported underdeveloped countries by giving them favorable market access. Thus, in the 1980s, investors took advantage of the export quotas, making T\&G a strategic sector of Bangladesh's economy. The phasing out of the quota system in 2005, however, gave rise to skepticism about the competitiveness of Bangladesh's RMGs and its prospects of continued success (Joarder, Hossain \& Hakim, 2010).

Interestingly, Bangladesh survived the phasing-out period and remains internationally competitive to date (ibid). One of the reasons for this is that the country has preferential market access to its major export destinations, which are now sources of enhanced revenue. It enjoys preferential treatment under the Everything But Arms (EBA) initiative in the European Union (EU) and respective Generalized System of Preference (GSP) schemes in countries including Canada, Japan and the US (Rahman, 2014).

In 2011, under the South Asian Free Trade Agreement (SAFTA) Revision Phase II, ${ }^{1}$ India allowed similar special concessions to the LDCs in the region. The Phase II revision aimed mainly at reducing the sensitive list ${ }^{2}$ maintained by SAFTA signatories by 20 percent. India granted the highest

\footnotetext{
${ }^{1}$ This was effective from 1 January 2012.

${ }^{2}$ Sensitive lists include those products that are of special interest to member countries and are, therefore, exempted from low SAFTA tariffs.
} 
concessions by reducing its sensitive list by 95 percent for the LDCs in the region. This entailed liberalizing its tariff lines from 480 items to 25 items, inter alia, and providing duty-free-quota-free access (DFQF) to 46 tariff lines pertaining to RMGs of which it had been cautious (Table A1 in the Appendix). For the nonleast developing countries (NLDCs) in the region, which included Pakistan and Sri Lanka, the sensitive list was reduced from 868 items to 614 items.

This DFQF access to the Indian market was seen as a window of opportunity for Bangladesh's RMG exports to penetrate the largest market in the region. Unfortunately, this failed to materialize. The aims of this study are to analyze pre- and post-revision trends in India's RMG imports from Bangladesh for the periods 2010-12 (before revision) and 2013-15 (after revision), and to investigate the underlying factors hindering the growth of these imports. Accordingly, we focus on the following questions:

- If both India and Bangladesh export the same products in the RMG sector, which country enjoys a higher comparative advantage in production?

- Is there any trade complementarity between Bangladesh and India, i.e., does the former export RMGs while the latter imports RMGs?

To address these questions, we calculate the revealed comparative advantage (RCA) for both countries' RMG exports, using data at the HC 4digit level for the period 2010-14. We also construct a trade complementarity index (TCI) using data at HC 6-digit level for the same years. The study reveals that Bangladesh enjoys a higher RCA in all major product lines and thus has a higher comparative advantage than India in RMG production. The TCI shows that there is no trade complementarity between the two countries: both export RMGs and are essentially competitors.

This paper is divided into 6 sections. Section 2 reviews the subject literature. Section 3 presents an overview of bilateral trade relations between Bangladesh and India. Section 4 calculates the RCA and demonstrates the strong position enjoyed by Bangladesh. It also analyzes pre- and post-revision trends in Indo-Bangladesh trade in RMGs. Section 5 explains why Bangladesh's RMGs have failed to penetrate the Indian market by calculating the TCI, comparing costs in both countries and examining the prevalence of nontariff barriers (NTBs) in India. Section 6 concludes the study. 


\section{Literature Review}

Following the success of other regional blocs, seven South Asian countries - Bangladesh, Bhutan, India, the Maldives, Nepal, Pakistan and Sri Lanka - formed SAARC in 1985 to cooperate mutually on economic, social and cultural fronts. With economic cooperation being at the heart of the agreement, a framework for regional integration - the South Asian Preferential Trade Agreement (SAPTA) - was approved in 1993 and implemented in 1995. This was considered a precursor to SAFTA. SAPTA was based on a positive-list approach, with negotiations centering on individual products. This proved time-consuming, while political rivalries meant that the most commonly traded goods were not considered for preferential tariffs. Ultimately, the agreement became redundant (Kelegama, 2007).

SAFTA began in 2006 and was based on a negative-list approach with an eight-year phasing-out period. Although the agreement was better articulated and envisaged a vigorous trade environment - that would come about by facilitating specialization, reducing tariffs, removing NTBs, expanding production capacities and improving technology - it has not lived up to its potential. Intra-SAARC trade remains around 4 percent of the total trade in the region (Taneja, Ray, Kaushal \& Chowdhury, 2011). Nadkarni (2014) calculates the total value of intra-regional SAARC exports to be US\$ 3 billion in 2013, which is far smaller than it should be.

The core reason for this is that SAFTA has applied a sensitive-list approach whereby members maintain a list of items that are deprived of concessional tariffs to protect local industries not fit for competition. This has restricted trade: Weerakoon and Thennakoon (2006) and Weerakoon (2010) estimate that 53 percent of South Asia's total intra-regional import trade is excluded from the Tariff Liberalization Program under SAFTA. IndoPakistan rivalry is cited as a preeminent reason for the stunted success of SAARC: were the two countries able to maintain cordial relations, the region's trade prospects would be magnified.

Numerous studies - using gravity models, computable general equilibrium and partial equilibrium - have attempted to ascertain the economic gains of regional integration in South Asia. Their findings indicate mixed results. Coulibaly (2005) concludes that SAFTA should result in net export creation, whereas Srinivasan and Canonero (1995) and Banik and Sengupta (1997) show that the impact of free trade is far larger for smaller countries in the region than for India. Contrary to this, Rahman (2003) finds 
the dummy variable for South Asia to be insignificant, indicating that regional integration is unlikely to generate significant trade expansion in this region.

Bayson, Panagariya and Pitigala (2006) argue that SAFTA has a fairly high likelihood of diverting rather than creating trade, given that member countries' most efficient suppliers were unlikely to be located in the region. Their study highlights three main reasons for this. First, any free trade agreement among SAARC countries is economically unattractive if India is excluded, considering their nominal share of GDP and world trade flows. Second, all countries except for Sri Lanka maintain high tariffs. Third, the political economy of selection, whereby certain sectors are excluded from preferential tariffs, gives rise to strong lobbies advocating their respective interests. The spirit of a regional trade agreement (RTA) is, essentially, to "create trade," thereby enhancing welfare.

However, critics have raised concerns that this might not reduce import prices in domestic markets - for instance, Indian exporters might find Bangladesh a "captive market" for their exports and charge prices at par with international markets (World Bank, 2006). Rahman, Shadat and Das (2006) show that Bangladesh, India and Pakistan would gain more from an RTA than Nepal, the Maldives and Sri Lanka. In terms of real income, however, India and Sri Lanka would perform better than Bangladesh.

The SAFTA (Phase II) revisions are an attempt by member countries to strengthen intra-regional trade. India has granted the most concessions to the region's LDCs, which gives them a chance to access South Asia's largest market. Among these, Bangladesh is a particularly interesting case for two reasons. First, it has always been subject to a bilateral trade deficit with India and this presents an opportunity to reduce the trade gap. Second, Bangladesh is the second-largest exporter of RMGs in the world; preferential access to India could provide another potential export market.

Given the high protection level of around 65.5 percent until 2004, it was difficult for Bangladeshi garments to penetrate the Indian market (World Bank, 2006). However, under preferential market access, Bangladeshi garments have begun to compete with domestic manufacturers in India and interested Indian investors, who have invested around US\$ 80 million in 35 garment factories in Bangladesh (Islam, Raihan \& Mollah, 2013). This concession has given the country an opportunity to explore the third-largest export destination for its garment commodities, following the EU and the US (ibid). 
However, the extent to which Bangladesh will benefit from these concessions is still questionable due to inherent issues within SAARC. The lack of similarity between Bangladesh's exports and India's imports restricts their trade complementarity (Basu \& Datta, 2007). This is tested empirically by Mayer and Wood (2001), using cross-country regressions. They conclude that South Asia's exports are concentrated in labor-intensive products, in which the region has a comparative advantage. Wood and Calandrino (2001) emphasize that the low level of education in India means that its comparative advantage in manufacturing still lies in labor-intensive products such as clothing and footwear.

Other impediments to the success of these concessions are concentrated in NTBs. The literature on Indo-Bangladesh trade agrees on the need to enhance infrastructure - the region is notorious for weak border trade. Cross-border transactions incur substantial costs in terms of time and expense, thereby exacerbating inefficiencies. Although many documentation procedures have been simplified, the transaction costs of India's exports to Bangladesh have risen (De \& Ghosh, 2008). Infrastructural and transport improvements are, therefore, key to increasing trade between the two countries (Acharya \& Marwaha, 2012).

\section{Bilateral Trade Relations Between Bangladesh and India}

As the largest market in SAARC, India enjoys a trade surplus with all other countries in the region, especially those that are LDCs. The largest volume of trade is with Bangladesh, which translates into the largest trade surplus. Overall, India's trade surplus with Bangladesh has increased from US $\$ 1.6$ billion to US $\$ 5.5$ billion over 2003-13, reflecting a deterioration in the latter's trade deficit with India (see Figure 1). Although India is one of Bangladesh's top five importers, its exports to Bangladesh are only 2 percent of its total exports. Thus, trade relations between the two countries are skewed in favor of India. 
Figure 1: Bilateral trade between India and Bangladesh

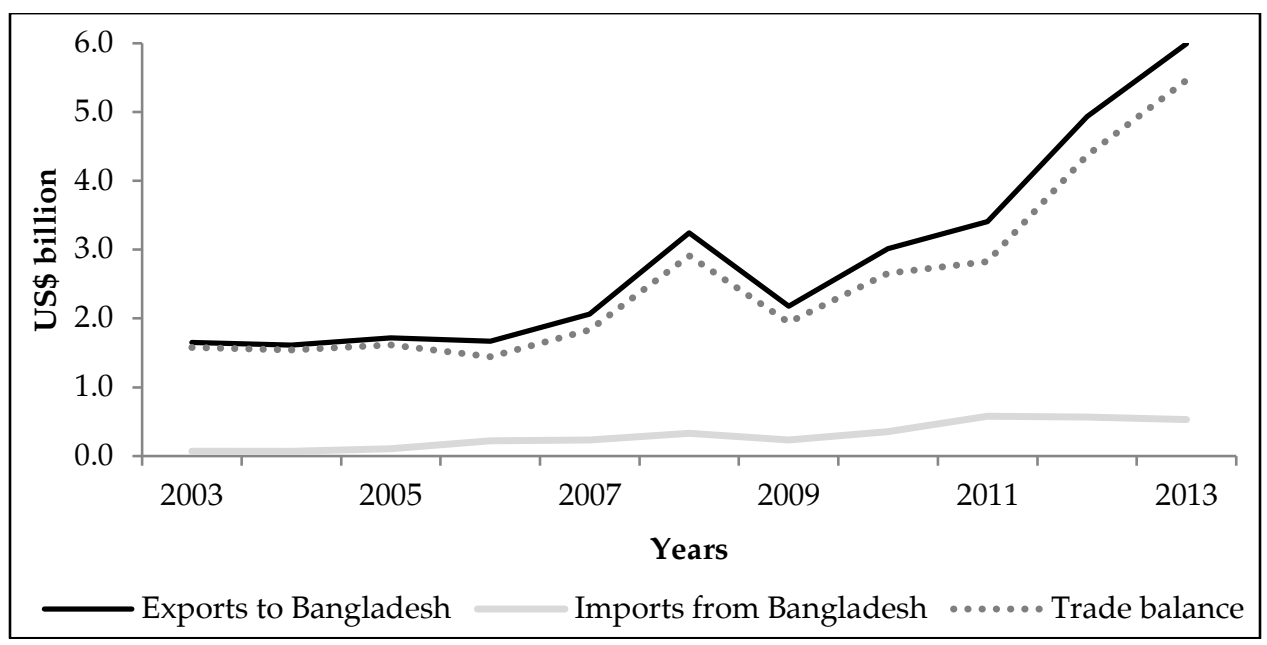

Source: UN Comtrade.

During 2003 to 2013, India's exports to Bangladesh showed an increasing trend. In 2003, they amounted to US\$ 1.65 billion, rising to US\$ 3.24 billion by 2008. Despite a slight decline in 2009 to US\$ 2.18 billion, exports continued to increase thereafter, reaching US\$ 6 billion in 2013. In comparison, India's imports from Bangladesh have remained low, amounting to US\$ 71 million in 2003 and increasing to US\$ 530 million in 2013. Imports rose from US\$ 358 million in 2010 to US\$ 579 million in 2013, remaining in this range. This can be attributed to the SAFTA Phase II revisions under which the number of items on the sensitive list was reduced to merely 25. However, the impact was not all that significant: observers had expected this provision of duty-free market access to increase Bangladesh's exports to India by 134 percent (De, Raihan \& Kathuria, 2012). Although Bangladesh has a comparative advantage over India in RMG production, its share of exports to India is meagre compared to that of other countries.

The Standard International Trade Classification (SITC) Revision 3 system categorizes all tradable commodities into ten groups. This helps us examine trends among the commodity groups that dominate India's exports to and imports from Bangladesh over the period 2003-13 (Tables A2 and A3 in the Appendix). The composition of India's exports to Bangladesh is restricted to a few commodity groups. The main sectors are food and live animals (SITC 0), crude materials (inedible, except fuels) (SITC 2), chemicals and related products (SITC 5), manufactured goods classified by material (SITC 6), and machinery and transport equipment (SITC 7). Exports of food 
and live animals have declined from 38.30 percent in 2003 to 21.80 percent in 2013 , while chemicals and related products have risen from 8.61 percent to 11.43 percent.

The major change has been the surge in crude materials (inedible, except fuels), which rose from 2.45 percent to 14.74 percent. Manufactured goods classified by material and machinery and transport equipment have maintained a consistent share over this period, averaging 27 percent and 14 percent, respectively. The main Indian export to Bangladesh is cotton (HS code 52), the core raw material for RMGs. Cotton exports to Bangladesh comprise 27 percent of India's total cotton exports (Table 2).

Table 2: India's cotton exports to Bangladesh

\begin{tabular}{lrrrrr}
\hline Cotton exports & $\mathbf{2 0 0 9 / 1 0}$ & $\mathbf{2 0 1 0 / 1 1}$ & $\mathbf{2 0 1 1 / 1 2}$ & $\mathbf{2 0 1 2 / 1 3}$ & $\mathbf{2 0 1 3 / 1 4}$ \\
\hline Value (US\$ million) & 455.29 & $1,081.39$ & $1,076.74$ & $1,505.76$ & $1,576.84$ \\
$\begin{array}{l}\text { As percentage of total } \\
\text { exports }\end{array}$ & 18.71 & 33.35 & 28.42 & 29.27 & 25.57 \\
\hline
\end{tabular}

Source: India, Ministry of Commerce and Industry.

Table 3 indicates an increasing trend in Bangladesh's cotton imports from 2009/10 to 2013/14, which rose from US\$3,397 million to US\$ 5,351 million. India is its second-largest source of cotton imports, accounting for 31 percent after 40 percent imported from China in 2013/14. Other main import sources include the US, Pakistan and Thailand.

Table 3: Cotton imports of Bangladesh

\begin{tabular}{llllll}
\hline & $\mathbf{2 0 0 9 / 1 0}$ & $\mathbf{2 0 1 0 / 1 1}$ & $\mathbf{2 0 1 1 / 1 2}$ & $\mathbf{2 0 1 2 / 1 3}$ & $\mathbf{2 0 1 3 / 1 4}$ \\
\hline $\begin{array}{l}\text { Cotton imports } \\
\text { (US\$ million) }\end{array}$ & $3,397.0$ & $4,321.0$ & $4,628.2$ & $5,288.5$ & $5,350.8$ \\
& & & & &
\end{tabular}

Major sources of cotton imports for Bangladesh (percentage)

\begin{tabular}{lrrrrr} 
China & 39.2 & 41.4 & 39.5 & 40.9 & 40.1 \\
India & 27.6 & 22.2 & 30.0 & 31.4 & 30.8 \\
Pakistan & 13.2 & 13.1 & 12.5 & 11.6 & 11.1 \\
US & 4.8 & 7.7 & 1.8 & 2.0 & 1.8 \\
Thailand & 1.8 & 1.6 & 1.2 & 1.3 & 1.1 \\
\hline
\end{tabular}

Source: International Trade Statistics. 
Imports from Bangladesh are concentrated in food and live animals (SITC 0), crude materials (inedible, except fuels) (SITC 2), chemicals and related products (SITC 5), manufactured goods classified by material (SITC 6) and miscellaneous manufactured articles (SITC 8). There has been a decline in crude materials (inedible, except fuels) from 29.26 percent in 2003 to 16.82 percent in 2013. Imports of chemicals and related products have deteriorated heavily from 40.45 percent in 2003 to 2.06 percent in 2013. Indian imports of manufactured goods and miscellaneous manufactured articles have increased from an average of 6-7 percent in 2003 to 31.32 and 32.94 percent in 2008 and 2013, respectively (Table A3 in the Appendix). The main items under these heads include leather and leather products, textile yarns and fabrics, and nonmetal mineral manufactures.

Table 4 gives the percentage contribution of major products to these classifications. Over the years, the shares of leather and nonmetal manufactures have declined, whereas that of textile yarns and fabrics has increased - largely explaining the increase in imports under these heads. Other than these, the main imports include fertilizers and jute products (De et al., 2012).

Table 4: Composition of manufactured goods and miscellaneous manufactured articles (percent)

\begin{tabular}{lrrr}
\hline Description & $\mathbf{2 0 0 3}$ & $\mathbf{2 0 0 8}$ & $\mathbf{2 0 1 3}$ \\
\hline Leather and leather goods & 20.66 & 7.05 & 3.78 \\
Textile yarns and fabrics & 60.35 & 75.36 & 82.75 \\
Nonmetal mineral manufactures & 16.85 & 15.90 & 9.98 \\
Other & 2.13 & 1.69 & 3.48 \\
Total & 100.00 & 100.00 & 100.00 \\
\hline
\end{tabular}

Source: UN Comtrade.

\section{Was the SAFTA (Phase II) Revision Successful?}

This section gauges whether the preferential treatment granted to Bangladesh by India has been successful. We calculate the RCA index for RMGs for both countries to ascertain which country enjoys a higher comparative advantage. Based on the rationale of comparative advantage, we examine the trends in trade under the concessions granted by India. 


\subsection{RCA Index}

RCA is used to assess a country's export potential for a particular commodity, thus indicating which exports warrant expansion. The RCA index of country $i$ for product $j$ is measured by the product's share of the country's exports in relation to its share of world trade:

$$
R C A_{i j}=\frac{X_{i j} / X_{i t}}{X_{w j} / X_{w t}}
$$

where $X_{i j}$ and $X_{w j}$ are, respectively, the value of country i's exports of product $j$ and world exports of product $j . X_{i t}$ and $X_{w t}$ refer to the country's total exports and world total exports, respectively. A value of less than unity implies that the country has a revealed comparative disadvantage in the product. Similarly, if the index exceeds unity, the country is said to have an RCA in the product.

Bangladesh has an average RCA of 33.3 percent in the production of RMGs compared to 2.3 percent for India (Table 5). This is because it has the distinctive benefit of a stock of cheap labor: the average monthly minimum wage is US\$ 68, which is the second-lowest in the world after Sri Lanka (International Labour Organization, 2014). This is accompanied by a set of supportive government policies, including cash compensation schemes, bonded warehouses, back-to-back letters of credit, duty drawback schemes and tax concessions, all of which make Bangladesh's RMG exports competitive in the international market.

Table 5: RCA for clothing

\begin{tabular}{lrrrrr}
\hline Country & $\mathbf{2 0 0 9}$ & $\mathbf{2 0 1 0}$ & $\mathbf{2 0 1 1}$ & $\mathbf{2 0 1 2}$ & $\mathbf{2 0 1 3}$ \\
\hline Bangladesh & 31.28 & 33.51 & 34.50 & 34.30 & 33.00 \\
India & 2.89 & 2.15 & 2.13 & 2.03 & 2.20 \\
\hline
\end{tabular}

Source: Author's calculations based on data from the WTO Statistics Database.

To investigate the competitive edge enjoyed by Bangladesh, we calculate its RCA at the HC 4-digit level for 11 products that dominate the country's exports (Table 6). ${ }^{3}$ For all these product lines, Bangladesh has a considerably high comparative advantage compared to India. The highest

\footnotetext{
${ }^{3}$ Product lines with exports increasing by US $\$ 500,000$ (for Bangladesh) are used for calculation.
} 
RCA is in men's shirts (6205), averaging around 83.5 compared to 4.1 for India. This is followed by knitted or crocheted $t$-shirts or vests (6109), with an average RCA of 70.6 as opposed to 3.4 for India, and by other products including jerseys and cardigans (6110), babies' garments and clothing (6111), and noncrocheted men's ensembles, suits, shirts and shorts (6203).

Of all the product lines mentioned, India has the largest advantage in the production of women's shirts and blouses (6206), averaging 7.8, although Bangladesh still has an RCA of 25.6. This is interesting because, for this particular product line, Indian exports outperform those of Bangladesh in absolute terms, amounting to US\$ 1.58 million in 2014 compared to US\$ 0.57 million for the latter (Table 7). 


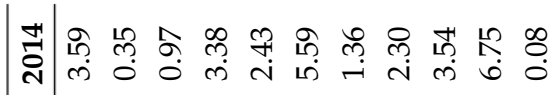

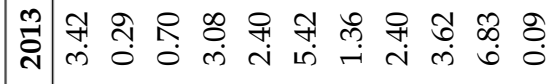

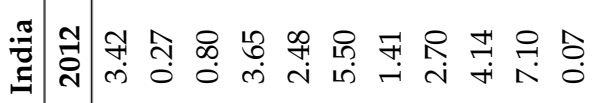

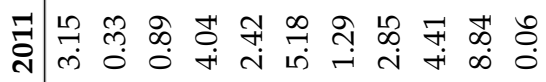

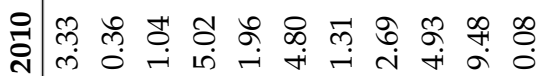

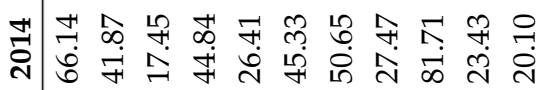
m ॠ ते सं ఫֶ)

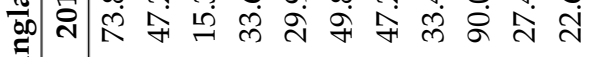

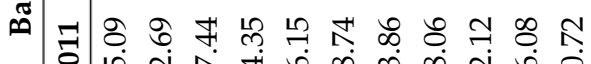
ปิ่

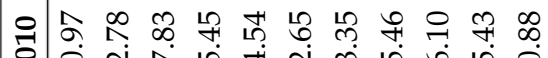

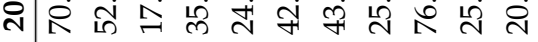

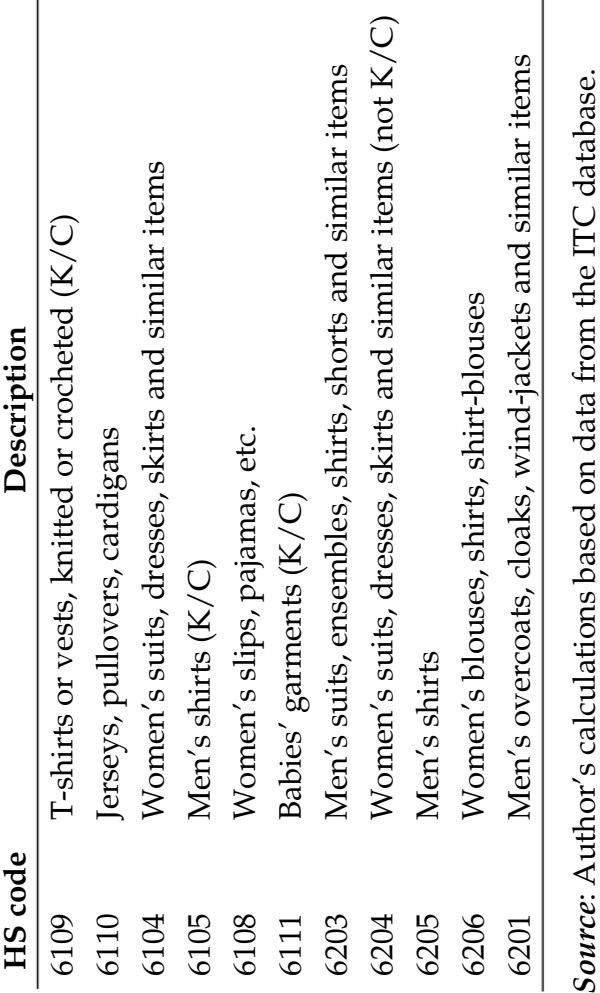


Table 7: Exports of women's blouses, shirts and shirt-blouses

\begin{tabular}{lrrrrr}
\hline Country & $\mathbf{2 0 1 0}$ & $\mathbf{2 0 1 1}$ & \multicolumn{1}{c}{$\mathbf{2 0 1 2}$} & \multicolumn{1}{c}{$\mathbf{2 0 1 3}$} & \multicolumn{1}{c}{$\mathbf{2 0 1 4}$} \\
\hline Bangladesh & 367,607 & 448,758 & 466,724 & 553,558 & 573,509 \\
India & $1,468,865$ & $1,709,830$ & $1,287,118$ & $1,596,554$ & $1,579,752$ \\
\hline
\end{tabular}

Note: Items classified under HS code 6206. All values in US\$ million.

Source: ITC database.

\subsection{Extent of Tariff Concessions Under the Revision}

Tariffs on textiles and clothing are lower in India than in Bangladesh (Table 8), but India maintains a dual tariff structure in these product groups whereby the charge is either ad valorem or a specific duty (whichever is higher). Pasha and Imran (2012) point out that the general specific duties are far higher, sometimes exceeding 100 percent, especially on value-added products; in some cases, the amount is even more than the binding tariffs under the World Trade Organization (WTO). They calculate the effective and ad valorem tariffs on textiles in India (see Table 9), which gives us a fair evaluation of the rates being charged.

Table 8: Average MFN-applied tariffs (percent)

\begin{tabular}{lcc}
\hline Product group & Bangladesh & India \\
\hline Textiles & 19.4 & 12.2 \\
Clothing & 24.4 & 13.0 \\
\hline
\end{tabular}

Source: World Tariff Profiles database.

Table 9: Distribution of effective and ad valorem tariffs on textiles in India (percent)

\begin{tabular}{lcc}
\hline Range & Rate & Percentage \\
\hline 0 to 10 & 35 & 15.7 \\
Above 10 to 25 & 83 & 37.2 \\
Above 25 to 50 & 61 & 27.4 \\
Above 50 to 100 & 31 & 13.9 \\
Above 100 & 13 & 5.8 \\
Total & 223 & 100.0 \\
\hline
\end{tabular}

Source: Pasha and Imran (2012).

Under the SAFTA Phase II revisions, India offered special concessions, reducing duty rates to 0 percent for LDCs, which meant DFQF 
access for Bangladesh's RMG exports to India. The scope of these concessions was viewed in the context of the EBA agreement between Europe and Bangladesh, which gave the latter a similar status to GSP-plus. It was presumed that exports would, therefore, follow a similar rising pattern. One of the main reasons for this prediction was the high comparative advantage enjoyed by Bangladesh, especially in articles of apparel (described by HS codes 61 and 62). This strengthened the rationale for expecting a surge in Bangladesh's RMG exports to India. The next section discusses the impact of these concessions on the trade patterns of both countries.

\subsection{Pre- and Post-Revision Trends in India's RMG Imports}

Given Bangladesh's robust position as a producer of the product lines listed in Section 4.1 vis-à-vis the theory of comparative advantage, we would expect its trade with India to have increased. Articles of apparel under HS codes 61 and 62, for example (Table 10), were predicted to penetrate the Indian market. However, imports of knitted or crotched articles of apparel (HS code 61) fell by 29 percent just after the year India granted preferential access. India's imports grew by 55 percent and then by 79 percent in 2014/15. The value of total imports was recorded at US\$ 30.6 million for 2014/15, which is negligible relative to its total imports of US\$ 448 million in this product category.

Imports of t-shirts and vests (6109) surged by 20 percent postrevision, reaching US\$ 3.28 million. Imports in this category have trended upward, reaching US\$ 15.6 million in 2014/15. Imports of knitted or crocheted cardigans and pullovers (6110) diminished two years after the revision, following which they increased from US\$ 1.51 million in 2013/14 to US\$ 6.87 million in 2014/15. A similar decline of 46 percent occurred in men's shirts (6105) post-revision, but imports of this product line gradually increased by 7.65 percent and 12.56 percent in subsequent years, reaching US\$ 1.5 million in 2014/15.

Other product lines denoted by HS codes 6104, 6108 and 6111 account for imports from Bangladesh approximating US\$ 1 million, an insignificant sum. Among these, the import value of babies' garments (6111) declined by 44 percent in 2014/15. Imports of articles of clothing not knitted or crocheted (HS code 62) account for relatively higher figures, but indicate a declining growth trend post-revision from 103 percent to 59 percent. This continued to deteriorate in subsequent years, falling to 51 percent in 2013/14 and to 17 percent in 2014/15. Overall, post-revision growth has averaged 42 percent, which is not particularly high. 


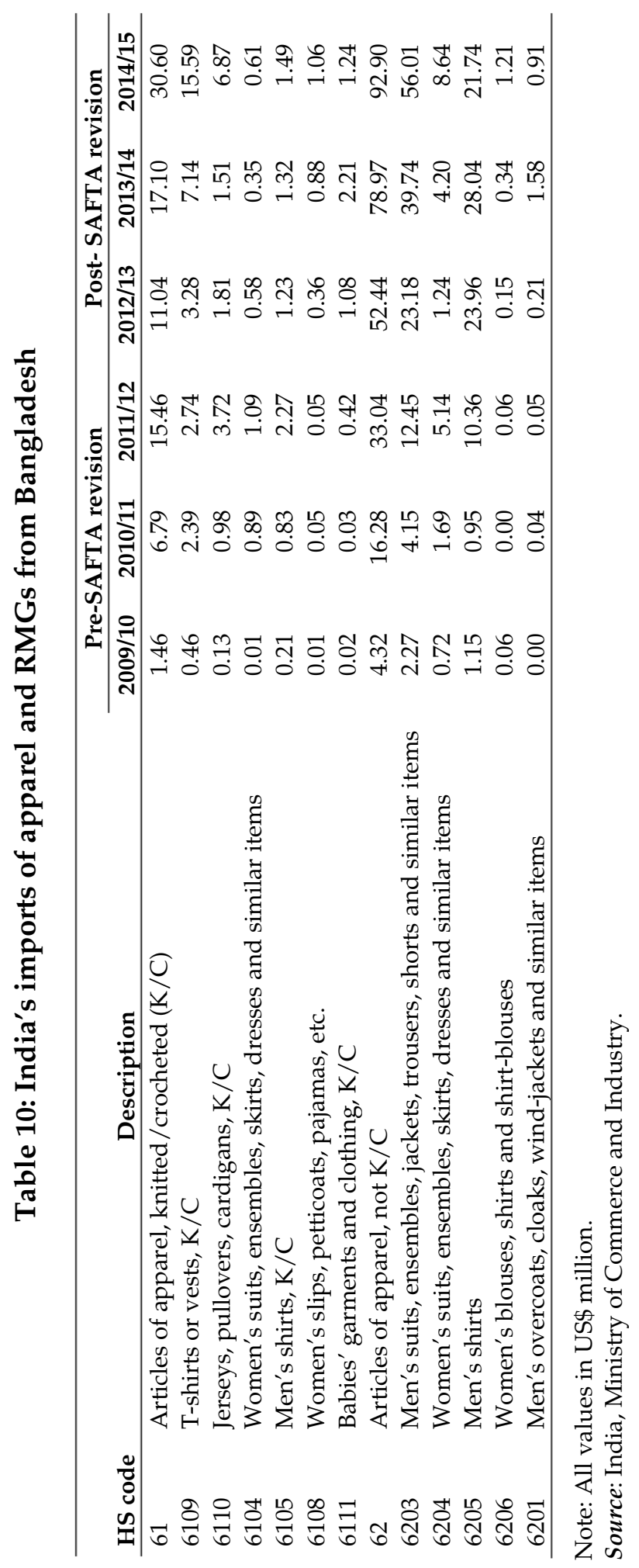


The highest imports are of men's ensembles, jackets and similar items (6203), accounting for US\$ 56 million in 2014/15. These imports increased just after the revision by 86 percent, after which they have gradually risen at a slower rate. Imports of women's suits, ensembles, skirts and similar items that are not knitted or crocheted (6204) declined postrevision, but then increased gradually, reaching US\$ 8.64 million in 2014/15.

Imports of men's shirts (6205) show a different trend, having increased by almost 1,000 percent pre-revision in 2011/12. They continued to grow at a declining rate until 2014/15, when they fell from US\$28 million in 2013/14 to US\$ 22 million. Other items that count as notable exports by Bangladesh include women's blouses (6206) and men's overcoats and cloaks (6201), but India's imports in these categories are only nominal. This is a striking trend because it implies that favorable market access has not yielded any extraordinary results, with imports from Bangladesh accounting for approximately US\$ 0.12 billion. In comparison, the US, which offers no equivalent preferential terms, has substantially higher RMG imports from Bangladesh, averaging about US\$ 1 billion.

In 2012, the then commerce minister of India, Anand Sharma, said that the concessions granted had "completely addressed the concerns of all SAARC LDC members as all items of their export interest are now allowed for import in India at zero duty." 4 Despite these assurances, the analysis of trade trends reveals that Bangladeshi RMGs have been unable to capture the Indian market. This begs the following questions: (i) why has there been no remarkable surge in Bangladesh's exports to India despite the duty-free regime and its higher RCA, and (ii) could these concessions potentially alter trade prospects in favor of Bangladesh?

\section{Impediments to Bangladesh's Exports}

This section seeks to answer the questions we have just raised by testing whether trade between Bangladesh and India is complementary or competitive, testing whether costs of production are higher in Bangladesh and examining the prevalence of NTBs in India.

\subsection{Trade Complementarity Between Bangladesh and India}

The TCI provides useful information on the prospects of intraregional trade, showing how well the structure of a country's imports and $4 \mathrm{http} / / /$ articles.economictimes.indiatimes.com/2012-02-17/news/31071455_1_sensitive-list-safta-
south-asian-free-trade 
exports match. The conventional index used to estimate trade complementarity is as follows:

$$
T C I_{j k}=1-\Sigma \frac{\left(\left|m_{i k}-x_{i j}\right|\right)}{2} \quad \text { where } 0 \leq \mathrm{TCI} \leq 1
$$

where $T C I$ represents trade complementarity between countries $j$ and $k, m_{i k}$ is the share of the $i$ th commodity in the total imports of country $k$ and $x_{i j}$ is the share of the $i$ th commodity in the total exports of country $j$. The higher the magnitude of the TCI, the greater will be the trade complementarity between the two countries.

The results show that, except in babies' garments (6111), the magnitude of trade complementarity between the two countries is considerably high. This implies that the supply of Bangladesh's exports matches a certain level of demand in India, indicating good prospects for intra-regional trade. However, this formula has a drawback: it ignores the possibility that a country might be both an importer and exporter. This is the case where India is concerned: not only does it import these product lines, but it is also a prominent exporter.

Table 11: TCI at HS code 6-digit level

\begin{tabular}{|c|c|c|c|c|c|c|}
\hline \multirow[t]{2}{*}{ HS code } & \multirow[t]{2}{*}{ Description } & \multicolumn{5}{|c|}{ TCI } \\
\hline & & 2010 & 2011 & 2012 & 2013 & 2014 \\
\hline 6109 & $\begin{array}{l}\text { T-shirts or vests, knitted or } \\
\text { crocheted }(\mathrm{K} / \mathrm{C})\end{array}$ & 0.70 & 0.73 & 0.69 & 0.66 & 0.67 \\
\hline 6110 & Jerseys, pullovers, cardigans & 0.73 & 0.62 & 0.75 & 0.77 & 0.76 \\
\hline 6104 & $\begin{array}{l}\text { Women's suits, dresses, skirts } \\
\text { and similar items }\end{array}$ & 0.53 & 0.50 & 0.45 & 0.45 & 0.42 \\
\hline 6105 & Men's shirts $(\mathrm{K} / \mathrm{C})$ & 0.96 & 0.91 & 0.98 & 0.97 & 0.96 \\
\hline 6108 & Women's slips, pajamas, etc. & 0.54 & 0.50 & 0.43 & 0.45 & 0.48 \\
\hline 6111 & Babies' garments (K/C) & 0.05 & 0.06 & 0.06 & 0.05 & 0.05 \\
\hline 6203 & $\begin{array}{l}\text { Men's suits, ensembles, shirts, } \\
\text { shorts and similar items }\end{array}$ & 0.66 & 0.67 & 0.72 & 0.68 & 0.65 \\
\hline 6204 & $\begin{array}{l}\text { Women's suits, dresses, skirts } \\
\text { and similar items (not K/C) }\end{array}$ & 0.58 & 0.58 & 0.60 & 0.59 & 0.53 \\
\hline 6205 & Men's shirts & 0.86 & 0.86 & 0.86 & 0.89 & 0.90 \\
\hline 6206 & $\begin{array}{l}\text { Women's blouses, shirts, shirt- } \\
\text { blouses }\end{array}$ & 0.74 & 0.68 & 0.59 & 0.51 & 0.50 \\
\hline 6201 & $\begin{array}{l}\text { Men's overcoats, cloaks, wind- } \\
\text { jackets and similar items }\end{array}$ & 0.64 & 0.78 & 0.80 & 0.83 & 0.81 \\
\hline
\end{tabular}

Source: Author's calculations based on data from the ITC database. 
Bangladesh's exports are concentrated in the RMG sector, which comprises 70-80 percent of its total exports, but only 6-7 percent of India's total exports. Despite this, India is a major exporter of $T \& G$ and was among the top 15 world clothing exporters in 2012, contributing about 3 percent to total world exports compared to 5 percent in Bangladesh's case (International Labour Organization, 2014).

Table 12 gives the export figures for garments and apparel under HS codes 61 and 62 for both countries. The main product line in which Bangladesh has a lead against India is knitted or crocheted apparel (HS code 61). India's trade has hovered around US\$ 4-7 billion in this category, whereas it has increased to US\$ 14 billion for Bangladesh - double the amount of Indian exports in this category. Exports of apparel that is not knitted or crocheted (HS code 62) have increased from US\$ 6 billion to US\$ 9 billion for India and from US\$ 7 billion to US\$ 14 billion for Bangladesh. Although the latter's growth in exports has been exceptional over the years, Indian exports have also trended upward.

Table 12: Total clothing exports (US\$ million)

\begin{tabular}{llcrrrr}
\hline HS code & Country & $\mathbf{2 0 0 9 / 1 0}$ & $\mathbf{2 0 1 0 / 1 1}$ & $\mathbf{2 0 1 1 / 1 2}$ & $\mathbf{2 0 1 2 / 1 3}$ & $\mathbf{2 0 1 3 / 1 4}$ \\
\hline 61 & India & 4,566 & 5,807 & 5,466 & 6,959 & 7,482 \\
& Bangladesh & 9,449 & 11,842 & 11,519 & 13,218 & 14,759 \\
62 & India & 6,038 & 7,937 & 7,430 & 8,743 & 9,056 \\
& Bangladesh & 7,478 & 9,982 & 11,322 & 13,359 & 14,145 \\
\hline
\end{tabular}

Source: ITC database.

Table 13 provides deeper insight into Indian export trends within the product categories that are Bangladesh's most prominent exports. For all products except for women's blouses (6206), Bangladesh has higher export values with increasing trends, but India has replicated this pattern, maintaining continuous growth in these product lines. Essentially, it is competing with Bangladesh. 
Table 13: Exports by product lines (US\$ ‘000)

\begin{tabular}{|c|c|c|c|c|c|}
\hline Code/country & 2010 & 2011 & 2012 & 2013 & 2014 \\
\hline \multicolumn{6}{|l|}{ HS code 6109} \\
\hline Bangladesh & $3,298,320$ & $4,307,533$ & $4,171,696$ & $4,566,341$ & $5,141,855$ \\
\hline India & $1,697,994$ & $2,073,624$ & $2,093,953$ & $2,600,305$ & $2,721,750$ \\
\hline \multicolumn{6}{|l|}{ HS code 6108} \\
\hline Bangladesh & 345,697 & 419,980 & 468,835 & 545,379 & 619,492 \\
\hline India & 295,748 & 437,065 & 414,041 & 518,898 & 544,158 \\
\hline \multicolumn{6}{|l|}{ HS code 6105} \\
\hline Bangladesh & 359,613 & 456,818 & 421,386 & 566,371 & 732,218 \\
\hline India & 545,803 & 603,645 & 486,767 & 495,366 & 528,083 \\
\hline \multicolumn{6}{|l|}{ HS code 6111} \\
\hline Bangladesh & 306,916 & 421,979 & 440,082 & 545,476 & 592,265 \\
\hline India & 370,330 & 504,040 & 517,539 & 656,646 & 698,232 \\
\hline \multicolumn{6}{|l|}{ HS code 6203} \\
\hline Bangladesh & $2,183,794$ & $2,831,601$ & $2,954,332$ & $3,523,764$ & $4,545,863$ \\
\hline India & 708,829 & 932,386 & 942,380 & $1,104,634$ & $1,170,464$ \\
\hline \multicolumn{6}{|l|}{ HS code 6204} \\
\hline Bangladesh & $1,659,382$ & $2,217,547$ & $2,622,953$ & $3,072,439$ & $3,221,717$ \\
\hline India & $1,876,276$ & $2,528,932$ & $2,255,945$ & $2,456,203$ & $2,580,624$ \\
\hline \multicolumn{6}{|l|}{ HS code 6206} \\
\hline Bangladesh & 367,607 & 448,758 & 466,724 & 553,558 & 573,509 \\
\hline India & $1,468,865$ & $1,709,830$ & $1,287,118$ & $1,596,554$ & $1,579,752$ \\
\hline
\end{tabular}

Source: ITC database.

This reinforces the notion that India itself is a major RMG exporter and, hence, a competitor of Bangladesh. Figure 2 shows that India, despite facing dynamic competition from low-cost producers such as Vietnam and Bangladesh, has sustained an average 3 percent contribution to world clothing exports. On the other hand, Bangladesh's competitive edge is reflected in its growing share of world clothing exports, which has increased from 3 to 5 percent in five years. Overall, it means that this is one of India's major export segments, which explains why the concessions it has granted have yielded no significant results for Bangladesh. 
Figure 2: Share of world clothing exports

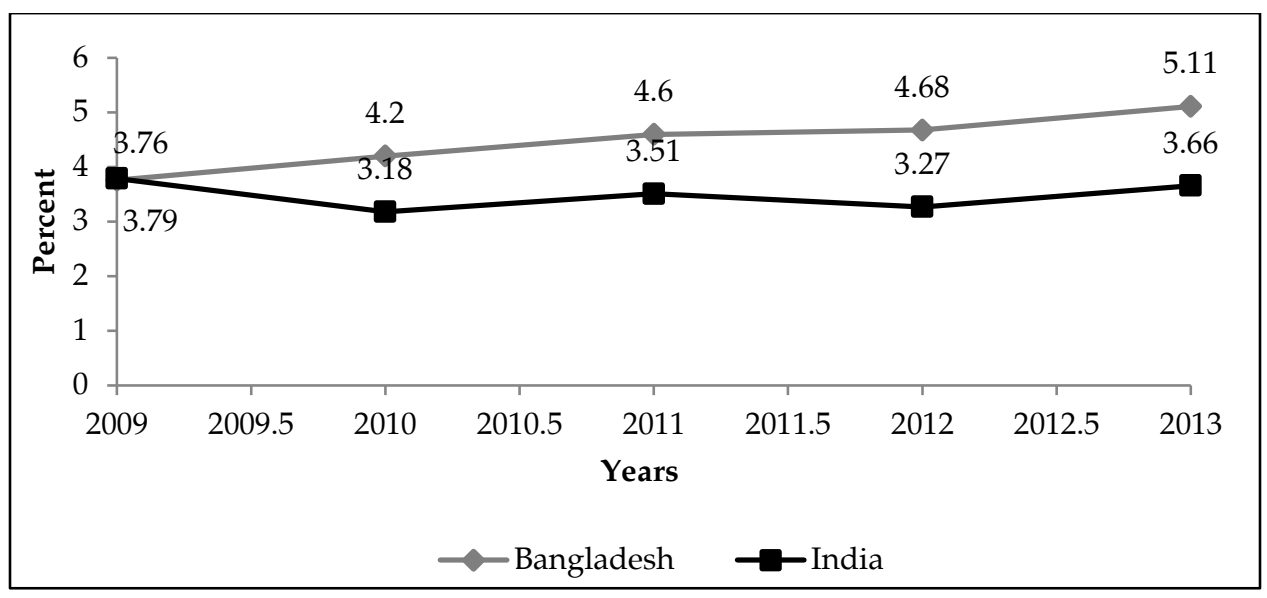

Source: WTO Statistics Database.

\subsection{Comparing Costs}

Despite its high RCA, India has managed to maintain a stable position and sustain its noncomplementarity vis-à-vis Bangladesh because it enjoys economies of scale in production, which makes the cost per unit lower and more competitive. Balassa's RCA index takes into account a country's exports of a particular product as a percentage of its total exports relative to the rest of the world - no other information on costs or factors of production is considered (Siggel, 2007). Thus, higher exports for a certain country can result from subsidies or other incentives such as favorable terms, as in the case of Bangladesh and its EU trading partners. This makes the index a deceptive measure of comparative advantage because India continues to produce the same RMG lines in which it has a far lower RCA than Bangladesh.

Nathan Associates (2009) have calculated the cost of producing and exporting a t-shirt for a given set of RMG producers. For India, the factory gate cost per garment is US\$ 1.084, whereas it is US\$ 1.097 for Bangladesh. This is despite the fact that Bangladesh has a lower labor cost, estimated at US\$ 0.32 per hour compared to US\$ 0.83 for India. Bangladesh's cost is higher because it incurs a fabric cost per kilogram of US\$ 3.336 for material imported from China and an additional shipping cost of US\$ 0.060. India, on the other hand, has a fabric cost per kilogram of US\$3.019, which is usually locally manufactured and has no associated shipping cost. The fully landed cost per garment is also slightly lower for India: US\$ 1.572 compared to US\$ 1.595 for Bangladesh (see Table A4 in the Appendix). 
Table 14 shows that, for all products pertaining to HS codes 61 and 62 at the 6-digit level, both India and Bangladesh had an equal volume of products with a lower cost per unit relative to each other in 2009. However, in 2011, India had a lower cost per unit for 92 percent of these products compared to Bangladesh. Clearly, India enjoys a lower cost per unit in production and benefits from economies of scale.

Table 14: Cost per unit (percent)

\begin{tabular}{lcc}
\hline Products with low cost per unit & $\mathbf{2 0 0 9}$ & $\mathbf{2 0 1 1}$ \\
\hline For Bangladesh & 46.75 & 1.30 \\
For India & 46.75 & 92.21 \\
No data available & 6.49 & 6.49 \\
\hline
\end{tabular}

Note: Calculated for the latest data available. This includes all products with sales exceeding US\$ 1 million, pertaining to HS codes 61 and 62 at the 6-digit level.

Source: UN Comtrade.

\subsection{Indian Export Incentives and NTBs}

Prior to 1994, India had a restrictive import regime under which T\&G imports were banned. Since then, it has liberalized its trade regime considerably and is the only NLDC in SAARC to have extended preferential treatment to the region's LDCs under Article 11. Having done so, however, India has also retained a system of export incentives and import restrictions in the RMG sector and thus artificially maintained a restrictive regime.

The Indian government has been keen to enhance the manufacturing sector of the economy and greatly emphasized $T \& G$ in this context. The apparel and RMG sector has huge export potential and the ability to simultaneously create employment opportunities. The Indian Ministry of Textiles estimates the value of current apparel exports at US\$ 45 billion and expects this to reach US $\$ 200$ billion by 2025 . In order to achieve this goal, the RMG sector is safeguarded via export incentive schemes.

These include special economic zones and export-oriented units that are given several incentives, such as income tax exemption for the first five years, duty-free imports and the procurement of domestic goods, exemption from central sales tax, and ease in clearance and customs procedures. Exportoriented manufacturers are given credit at subsidized rates and increased 
duty drawback rates for products pertaining to HC 61, 62 and 63, varying between 7 and 10 percent. ${ }^{5}$ Other recent incentives include the following:

- Scheme for integrated textile parks. This initiative aims to create state-ofthe-art infrastructure for the textiles industry. Given the significance of women's employment in the apparel sector, the finance minister has allocated additional funds for apparel units within these parks. ${ }^{6}$

- Incubation centers in apparel manufacturing. This scheme intends to encourage entrepreneurship in apparel manufacturing, enhance manufacturing capacity and create more job opportunities. The initiative aims to provide an integrated workspace that will help startup businesses operationally and financially. ${ }^{7}$

- Integrated skills development scheme. This is a training program developed to impart the skills the industry needs that will allow firms to compete globally (India, Ministry of Textiles, 2013).

These export incentives, when combined with the provision of nontariff measures (NTMs), impede RMG imports. Import restrictions such as import licensing or NTMs are interventions applied by the Indian government to control domestic supplies. For instance, NTMs for the RMG sector are a way of protecting and promoting the domestic industry. Some of the main NTMs imposed by India include the following:

- Customs clearance. This is a time-consuming and complex procedure. Importers have to register with the Directorate General of Foreign Trade and acquire an importer-exporter code in order to import goods commercially. The documents required for clearance include a bill of entry, invoices, a packing list and a bill of lading. Other requirements might include an import license or country-of-origin certificate (CUTS International, 2014). On average, import procedures take 21 days to complete, which includes eight days to prepare the necessary documents and four days for customs clearance and technical inspections. The total cost incurred per container is US\$ $1,462 .{ }^{8}$

- Pre-shipping requirements. The import of textile-related products requires a pre-shipment inspection certificate from a textile-testing laboratory accredited to the national accreditation agency of the

\footnotetext{
${ }^{5}$ The drawback duty rates are available from the Apparel Export Promotion Council of India at http://www.aepcindia.com/app/webroot/img/pdf/New-Duty-Drawback-2012-13.pdf

${ }^{6} \mathrm{http} / / /$ texmin.nic.in/policy/guidelines\%20of\%20apparel\%20manufacturing\%20units.pdf

${ }^{7} \mathrm{http}: / /$ texmin.nic.in/policy/Incubation_Scheme_Guidelines_Final.pdf

${ }^{8} \mathrm{http} / / /$ www.doingbusiness.org/data/exploretopics/trading-across-borders
} 
country of origin (WTO, 2011). Failure to provide this means that the importer must acquire this certificate from a designated lab in India. The rules on this are strict and even certificates issued by EU-accredited labs have been rejected by Indian customs authorities, with such consignments then being subject to repeat tests in India (WTO, 2011).

- Port of destination. Apparel must be imported through Jawaharlal Nehru Port in Mumbai. ${ }^{9}$ This is an artificial barrier created by the Indian authorities. Goods from Bangladesh have to travel 2,320 nautical miles to reach Mumbai whereas the neighboring port of Kolkata involves a distance of 361 nautical miles.

- Labeling requirements. Indian imports must be labeled in Hindi (Devanagari script) as well as in English and comply with Indian standards. Failure to do so leads to nonclearance of the good being imported. ${ }^{10}$

- Lack of infrastructure. Infrastructural bottlenecks are one of the main hindrances to cross-border trade between India and Bangladesh. Most land trade is carried out across the Petrapole-Benapole border. The Indian side is marred by inefficiencies and lack of quality infrastructure. Inadequate warehouses, parking, cold storage facilities, stationery, goods scanners and weighbridges, etc., create delays in trade transactions and add to the cost.

Combined, these factors make RMG exports from Bangladesh less attractive, which explains why the forecasted surge did not emerge. India itself is catching up with an apparel and RMG export regime, attempting to sustain its position in the world market.

\section{Conclusion}

This paper has sought to investigate the trends in Bangladesh's RMG exports to India following the SAFTA revisions (Phase II) under which the sensitive list for LDCs was reduced to 25 items (mainly tobacco and beverages). Given Bangladesh's high comparative advantage, observers expected that its RMG exports would penetrate the Indian market, but this failed to materialize. Thus, our first key finding is that the concessions granted by India to Bangladesh (which include a status similar to GSP-plus) have not yielded any remarkable surge in the latter's RMG exports to India.

\footnotetext{
${ }^{9} \mathrm{http}: / /$ web.ita.doc.gov/tacgi/OverSeasNew.nsf/alldata/India\#Documentation

${ }^{10} \mathrm{http} / / /$ web.ita.doc.gov/tacgi/OverSeasNew.nsf/alldata/India\#Documentation
} 
A key factor in this is the absence of effective trade complementarity between the two countries - an issue highlighted by Basu and Datta (2007). One reason for this is the similarity in resource endowments within the region due to which these countries have a common comparative advantage in labor-intensive manufacturing goods (Mayer \& Wood, 2001). The lack of complementarity undermines the effectiveness of the preferential access granted to Bangladesh. Additionally, South Asia is marred by an economic power asymmetry whereby India, the region's dominant player, enjoys a larger market, better production capacities and economies of scale relative to its neighbors.

The situation is aggravated by the artificially secure regime that India maintains, given its position as a prominent RMG exporter and competitor of Bangladesh. India strategically combines export promotion incentives with different NTMs in order to restrict imports, creating hurdles for Bangladesh's exports by making them less attractive and uncompetitive for local traders. Thus, the second key finding is that India has maintained a nonmonetary secure regime for its $T \& G$ sector by playing on both the demand and supply sides, and introducing export incentives and NTMs that hinder RMG imports from Bangladesh. These measures, once adopted, make imports costlier and less competitive, thereby allowing India to combat low-cost competition from countries such as Bangladesh, Vietnam and Cambodia.

It also explains the anomaly we have discussed. Bangladesh has a significantly higher comparative advantage for all the product categories that occupy a pivotal place in its export portfolio. However, India trades in all these product lines as a competitor. This extent of "fruitless" liberalization by India raises several key questions, the first and foremost of which concerns the use of RCA as a measure of comparative advantage among countries. While the index might work in some instances, it is inadequate when comparing countries with similar factor endowments, such as those in South Asia.

Comparative advantage does not have to be the sole cause of international trade when increasing returns or economies of scale can also lead to specialization and trade (Krugman, 1987). Thus, when looking at comparative advantage, it is also worth considering production capacities, technological advancements and unit costs of production to obtain an accurate picture. Mayer and Wood (2001) show that economies of scale are important in explaining the volume and composition of trade among countries with similar factor endowments. Hence, the third key finding is 
that, while Balassa's RCA index reflects a country's success as an exporter relative to a worldwide norm, it is a deceptive measure of comparative advantage. In essence, it is a measure of competitiveness. India, on the other hand, enjoys a lower cost per unit and benefits from economies of scale. It contributes 3 percent to world clothing exports compared to 5 percent for Bangladesh. This underscores the former's stronghold in this sector and its position as a competitor. As a result, the concessions granted by India have failed to draw any positive or favorable trade trends for Bangladesh.

The main question that emerges from the analysis is whether India's attempt to liberalize trade reflects any intention of benefiting the LDCs in the region. Considering the NTBs it has imposed, India appears to be applying a dual policy. That said, the answer to this question is complex. Although India is striving to become the region's manufacturing hub, more time is needed to monitor trends in Indo-Bangladesh trade before drawing an effective conclusion.

Political mistrust in South Asia has also diluted the real concept of RTAs, which is to develop "deep integration" in the region. As Newfarmer and Piérola (2007) explain, RTAs succeed only when new competition emerges, which results in price reductions and the acquisition of new technology. For SAFTA to be successful, its partner economies need to work in collaboration and develop regional value chains for products such as RMGs - depending on their competitive edge - and engage in intra-regional trade. This would strengthen regional productivity and countries' bargaining capacity, in turn ensuring greater profits and inclusive growth. Resolving political disputes and eliminating NTMs within the region could be a first step toward the success of SAFTA. 


\section{References}

Acharya, L., \& Marwaha, A. (2012). Status paper on India-Bangladesh economic relations. New Delhi: Federation of Indian Chambers of Commerce and Industry.

Banik, A., \& Sengupta, N. (1997). Regional trade and investment: Case of SAARC. Economic and Political Weekly, 32(46), 15-21.

Basu, S., \& Datta, D. (2007). India-Bangladesh trade relations: Problem of bilateral deficit. Indian Economic Review, 42(1), 111-129.

Bayson, T., Panagariya, A., \& Pitigala, N. (2006). Preferential trading in South Asia (Policy Research Working Paper No. 3813). Washington, DC: World Bank.

Coulibaly, S. (2005, March). On the assessment of trade creation and trade diversion effects of developing RTAs. Paper presented at the Annual Meeting of the Swiss Society of Economics and Statistics, Zurich.

CUTS International. (2014). India-Bangladesh trade potentiality: An assessment of trade facilitation issues. Jaipur: Author.

De, P., \& Ghosh, B. (2008). Reassessing transaction costs of trade at the IndiaBangladesh border. Economic and Political Weekly, 43(29), 69-79.

De, P., Raihan, S., \& Kathuria, S. (2012). Unlocking Bangladesh-India trade: Emerging potential and the way forward (Policy Research Working Paper No. 6155). Washington, DC: World Bank.

India, Ministry of Textiles. (2013). Integrated skill development scheme for the textiles and apparel sector including jute and handicrafts. Retrieved from http://texmin.nic.in/sites/default/files/ISDSguidelinesJuly2013.pdf

International Labour Organization. (2014). Wages and working hours in the textiles, clothing, leather and footwear industries (Issues paper for discussion at the Global Dialogue Forum on Wages and Working Hours in the Textiles, Clothing, Leather and Footwear Industries). Geneva: Author. 
Islam, T., Raihan, A., \& Mollah, M. M. H. (2013). Is Bangladesh a beneficiary of South Asian Free Trade Area (SAFTA)? Journal of Economics and Development, 15(3), 36-58.

Joarder, M. A. M., Hossain, A. K. M., \& Hakim, M. M. (2010). Post-MFA performance of Bangladesh apparel sector. International Review of Business Research Papers, 6(4), 134-144.

Kelegama, S. (2007). Towards greater economic connectivity in South Asia. Economic and Political Weekly, 42(39), 3911-3915.

Krugman, P. R. (1987). Is free trade passé? Journal of Economic Perspectives, 1(2), 131-144.

Mahmood, T. (2000). SAARC and regional politics. Pakistan Horizon, 53(4), $7-21$.

Mayer, J., \& Wood, A. (2001). South Asia's export structure in a comparative perspective. Oxford Development Studies, 29(1), 5-29.

Nadkarni, V. (2014, July). India and SAARC. Paper presented at the FLACSO-ISA Joint International Conference, Buenos Aires.

Nathan Associates. (2009). Cost competitiveness of Pakistan's textiles and apparel industry. Washington, DC: United States Agency for International Development.

Newfarmer, R. S., \& Piérola, M. D. (2007). South Asia Free Trade Area: Promises and pitfalls of preferential trade arrangements. In Z. F. Naqvi \& P. Schuler (Eds.), The challenges and potential of PakistanIndia trade (pp. 29-58). Washington, DC: World Bank.

Otsubo, S. (1998). APEC and its developing members: An applied general equilibrium analysis of regional trading arrangement. Journal of International Development Studies, 7(1), 1-17.

Pasha, H. A., \& Imran, M. (2012). The prospects for Indo-Pakistan trade [Special edition]. Lahore Journal of Economics, 17, 293-313.

Rahman, M. M. (2003, September). A panel data analysis of Bangladesh's trade: The gravity model approach. Paper presented at the Fifth European Trade Study Group Conference, Madrid. 
Rahman, M. M. (2010). The factors affecting Bangladesh's exports: Evidence from the gravity model analysis. Journal of Developing Areas, 44(1), 229-244.

Rahman, M. (2014). Trade benefits for least developed countries: The Bangladesh case (CDP Background Paper No. 18). New York, NY: United Nations Department of Economic and Social Affairs.

Rahman, M., Shadat, W., \& Das, N. C. (2006). Trade potential in SAFTA: An application of augmented gravity model (Occasional Paper No. 61). Dhaka: Centre for Policy Dialogue.

Siggel, E. (2007, July). International competitiveness and comparative advantage: A survey and a proposal for measurement. Paper presented at the CESifo Venice Summer Institute, Venice.

Srinivasan, T. N., \& Canonero, G. (1995). Preferential trading arrangements in South Asia: Theory, empirics and policy. Unpublished manuscript, Yale University, New Haven, CT.

Taneja, N., Ray, S., Kaushal, N., \& Chowdhury, D. R. (2011). Enhancing intra-SAARC trade: Pruning India's sensitive list under SAFTA. New Delhi: ICRIER.

Weerakoon, D. (2010). The political economy of trade integration in South Asia: The role of India. The World Economy, 33(7), 916-927.

Weerakoon, D., \& Thennakoon, J. (2006). India-Sri Lanka FTA: Lessons for SAFTA. Jaipur: CUTS International.

Wood, A., \& Calandrino, M. (2001). When other giant awakens: Trade and human resources in India. Economic and Political Weekly, 35(52/53), 4677-4694.

World Bank. (2006). India-Bangladesh bilateral trade and potential free trade agreement (Bangladesh Development Series Paper No. 13). Dhaka: Author.

World Trade Organization. (2011). Trade policy review: India. Retrieved from https://www.wto.org/english/tratop_e/tpr_e/tp349_e.htm 
Appendix

Table A1: List of apparel and RMG products liberalized under SAFTA Revision (Phase II)

\begin{tabular}{|c|c|c|}
\hline S1 & $\begin{array}{l}\text { Chapter, heading, sub- } \\
\text { heading or tariff item } \\
\text { of the First Schedule }\end{array}$ & Description of goods \\
\hline 160 & 500720 & $\begin{array}{l}\text { Other woven fabrics of silk, containing } 85 \% \text { or more } \\
\text { by weight of silk or of silk waste other than noil silk }\end{array}$ \\
\hline 170 & 610342 & Men's or boys' trousers \\
\hline 171 & 610343 & $\begin{array}{l}\text { Men's or boys' trousers, overalls and shorts, knitted, } \\
\text { of synthetic fibers }\end{array}$ \\
\hline 178 & 610462 & $\begin{array}{l}\text { Women's or girls' trousers, overalls and shorts, } \\
\text { knitted, of cotton }\end{array}$ \\
\hline 179 & 610463 & All goods \\
\hline 181 & 610510 & All goods \\
\hline 182 & 610520 & All goods \\
\hline 183 & 610610 & All goods, knitted \\
\hline 185 & 610711 & All goods \\
\hline 187 & 610721 & All goods \\
\hline 189 & 610791 & All goods \\
\hline 191 & 610821 & All goods \\
\hline 192 & 610822 & $\begin{array}{l}\text { Women's or girls' briefs and panties, knitted or } \\
\text { crocheted, of manmade fibers }\end{array}$ \\
\hline 193 & 610831 & $\begin{array}{l}\text { Women's or girls' nightdresses and pajamas, knitted } \\
\text { or crocheted, of cotton }\end{array}$ \\
\hline 194 & 610910 & All goods \\
\hline 195 & 610990 & All goods \\
\hline 197 & 611020 & All goods \\
\hline 198 & 611030 & All goods \\
\hline 199 & 611090 & All goods \\
\hline 200 & 611120 & $\begin{array}{l}\text { Babies' garments and clothing accessories, knitted or } \\
\text { crocheted, of cotton }\end{array}$ \\
\hline 201 & 611130 & All goods \\
\hline 203 & 611241 & Of synthetic fibers \\
\hline 204 & 611300 & $\begin{array}{l}\text { Garments, made-up, of knitted or crocheted fabrics of } \\
\text { heading no. } 59.03,59.06\end{array}$ \\
\hline 205 & 611420 & All goods \\
\hline 208 & 611699 & All goods \\
\hline 210 & 620332 & All goods \\
\hline 211 & 620333 & All goods \\
\hline 212 & 620342 & $\begin{array}{l}\text { Men's or boys' trousers, overalls and shorts, woven, } \\
\text { cotton }\end{array}$ \\
\hline
\end{tabular}




\begin{tabular}{lcl}
\hline S1 & $\begin{array}{c}\text { Chapter, heading, sub- } \\
\text { heading or tariff item } \\
\text { of the First Schedule }\end{array}$ & \\
\hline 214 & 620413 & All goods \\
215 & 620452 & All goods \\
216 & 620462 & Women's or girls' trousers, overalls and shorts, \\
& 620520 & woven, cotton \\
217 & 620530 & Men's or boys' shirts, woven, cotton \\
218 & 620590 & Men's or boys' shirts, woven, manmade fibers \\
219 & 620630 & 'll goods \\
221 & 620721 & Women's or girls' blouses, shirts and shirt-blouses, \\
& 620821 & All goods \\
222 & 620920 & All goods \\
223 & 620930 & All goods except hats \\
224 & 621040 & All goods except hats \\
225 & 621050 & All goods \\
226 & 621111 & Sweaters, sweatshirts and waistcoats, knitted, cotton \\
227 & 621132 & All goods \\
228 & 621133 & All goods \\
229 & 621210 & All goods \\
230 & 621710 & All goods \\
233 & Made-up clothing accessories, woven \\
235 & &
\end{tabular}

Source: Bangladesh Garment Manufacturers and Exporters Association. 
Table A2: India's exports to Bangladesh

\begin{tabular}{llrrr}
\hline $\begin{array}{l}\text { SITC } \\
\text { code }\end{array}$ & \multicolumn{1}{c}{ Description } & $\mathbf{2 0 0 3}$ & $\mathbf{2 0 0 8}$ & $\mathbf{2 0 1 3}$ \\
\hline 0 & Food and live animals & 38.30 & 35.25 & 21.80 \\
1 & Beverages and tobacco & 0.26 & 0.10 & 0.01 \\
2 & Crude materials, inedible, except fuels & 2.45 & 11.89 & 14.74 \\
3 & Mineral fuels, lubricants and related materials & 5.23 & 3.93 & 2.70 \\
4 & Animal and vegetable oils, fats and waxes & 0.20 & 0.20 & 0.04 \\
5 & Chemicals and related products, n.e.s. & 8.61 & 8.65 & 11.43 \\
6 & Manufactured goods classified mainly by material & 29.03 & 24.15 & 28.30 \\
7 & Machinery and transport equipment & 13.33 & 13.42 & 15.81 \\
8 & Miscellaneous manufactured articles & 2.13 & 1.91 & 2.52 \\
9 & Commodities and transactions not classified & 0.48 & 0.49 & 2.65 \\
& elsewhere in SITC commodities and transactions & & & \\
Total & All commodities & 100.00 & 100.00 & 100.00 \\
\hline
\end{tabular}

Source: UN Comtrade.

Table A3: India's imports from Bangladesh

\begin{tabular}{llrrr}
\hline $\begin{array}{l}\text { SITC } \\
\text { code }\end{array}$ & \multicolumn{1}{c}{ Description } & $\mathbf{2 0 0 3}$ & $\mathbf{2 0 0 8}$ & $\mathbf{2 0 1 3}$ \\
\hline 0 & Food and live animals & 9.85 & 17.7 & 20.86 \\
1 & Beverages and tobacco & 0.31 & 0.28 & 0.73 \\
2 & Crude materials, inedible, except fuels & 29.26 & 11.18 & 16.82 \\
3 & Mineral fuels, lubricants and related materials & 2.56 & 7.01 & 3.38 \\
4 & Animal and vegetable oils, fats and waxes & 0.02 & 0.10 & 1.19 \\
5 & Chemicals and related products, n.e.s. & 40.45 & 27.81 & 2.06 \\
6 & Manufactured goods classified mainly by material & 7.71 & 31.32 & 32.94 \\
7 & Machinery and transport equipment & 1.93 & 1.87 & 1.77 \\
8 & Miscellaneous manufactured articles & 6.57 & 2.09 & 18.23 \\
9 & Commodities and transactions not classified & 1.35 & 0.63 & 2.01 \\
& elsewhere in SITC commodities and transactions & & & \\
Total & All commodities & 100.00 & 100.00 & 100.00 \\
\hline
\end{tabular}

Source: UN Comtrade. 
Table A4: T-shirt production cost estimates

\begin{tabular}{|c|c|c|c|c|c|c|}
\hline $\begin{array}{l}\text { Garment making up by } \\
\text { country }\end{array}$ & India & India & China & Pakistan & Bangladesh & Cambodia \\
\hline Fabric source & India & China & China & Pakistan & China & China \\
\hline \multicolumn{7}{|l|}{ Main fabric } \\
\hline Fabric cost per kg (US\$) & 3.019 & 3.336 & 3.336 & 2.894 & 3.336 & 3.336 \\
\hline $\begin{array}{l}\text { Fabric shipping cost per kg } \\
\text { (US\$) }\end{array}$ & 0.000 & 0.069 & 0.000 & 0.000 & 0.060 & 0.069 \\
\hline Fabric use per garment $(\mathrm{kg})$ & 0.235 & 0.235 & 0.235 & 0.235 & 0.235 & 0.235 \\
\hline $\begin{array}{l}\text { Fabric waste (short pieces, } \\
\text { end of rolls, faults) (\%) }\end{array}$ & 5 & 5 & 5 & 5 & 5 & 5 \\
\hline $\begin{array}{l}\text { Main fabric cost per } \\
\text { garment (US\$) }\end{array}$ & 0.710 & 0.801 & 0.784 & 0.680 & 0.798 & 0.801 \\
\hline \multicolumn{7}{|l|}{ Trim cost per garment (US\$) } \\
\hline Thread & 0.045 & 0.045 & 0.045 & 0.045 & 0.045 & 0.045 \\
\hline Labels, tags & 0.037 & 0.037 & 0.037 & 0.037 & 0.037 & 0.037 \\
\hline \multicolumn{7}{|l|}{ Packaging per garment (US\$) } \\
\hline Plastic poly bag & 0.018 & 0.018 & 0.018 & 0.018 & 0.018 & 0.018 \\
\hline Cardboard box/carton & 0.060 & 0.060 & 0.060 & 0.060 & 0.060 & 0.060 \\
\hline $\begin{array}{l}\text { Total materials cost per } \\
\text { garment }\end{array}$ & 0.870 & 0.961 & 0.944 & 0.840 & 0.958 & 0.961 \\
\hline $\begin{array}{l}\text { Labor-hour (\$) cost in } \\
\text { making up }\end{array}$ & 0.830 & 0.830 & 1.440 & 0.550 & 0.320 & 0.335 \\
\hline $\begin{array}{l}\text { Standard minutes per } \\
\text { garment cut-make-trim- } \\
\text { finish }\end{array}$ & 6.12 & 6.12 & 6.12 & 6.12 & 6.12 & 6.12 \\
\hline Efficiency adjustment & 25 & 25 & 15 & 30 & 50 & 70 \\
\hline $\begin{array}{l}\text { Labor cost per garment } \\
\text { (US\$) }\end{array}$ & 0.106 & 0.106 & 0.169 & 0.073 & 0.049 & 0.058 \\
\hline Reject garments ( $3 \%)$ & 0.029 & 0.032 & 0.033 & 0.027 & 0.030 & 0.031 \\
\hline $\begin{array}{l}\text { Manufacturing overhead } \\
\text { per garment }(25 \% \text { on labor) } \\
\text { (US\$) }\end{array}$ & 0.026 & 0.026 & 0.042 & 0.018 & 0.012 & 0.015 \\
\hline \multicolumn{7}{|l|}{$\begin{array}{l}\text { Inclusive of electricity, rent, } \\
\text { indirect labor }\end{array}$} \\
\hline $\begin{array}{l}\text { Sales and administration } \\
\text { costs }(10 \% \text { on labor) (US\$) }\end{array}$ & 0.011 & 0.011 & 0.017 & 0.007 & 0.005 & 0.006 \\
\hline \multicolumn{7}{|l|}{$\begin{array}{l}\text { Total cost per garment: fabric, } \\
\text { labor, overhead (US\$) }\end{array}$} \\
\hline Sales and administration & 1.042 & 1.136 & 1.206 & 0.966 & 1.055 & 1.070 \\
\hline $\begin{array}{l}\text { Agent fee per garment ( } 4 \% \\
\text { on total cost) }\end{array}$ & 0.042 & 0.045 & 0.048 & 0.039 & 0.042 & 0.043 \\
\hline
\end{tabular}

Source: Nathan Associates (2009). 